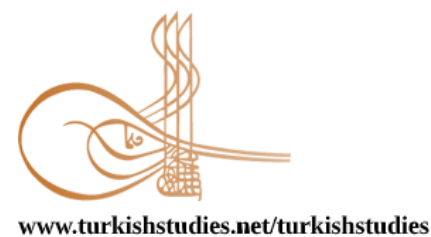

Turkish Studies

eISSN: $1308-2140$

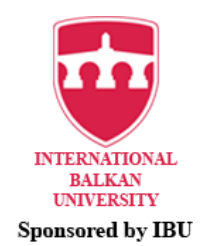

Research Article / Araștırma Makalesi

\title{
Bizans Döneminde Myra (Demre) Kenti Kırsalında Güvenlik: Ayıveliler Kalesi
}

The Defense in the Rural of Myra (Demre) City in the Byzantine Period: Ayiveliler Fortress

\author{
Bülent İşler*
}

\begin{abstract}
Myra, which constitutes the Demre district center of Antalya province, is an ancient coastal city located in the middle of the Lycian region, starting from Phaselis in the east and extending to the Gulf of Fethiye in the west. Myra developed during the Byzantine period and became the religious and administrative center of the Lycian region in the $5^{\text {th }}$ century. In terms of its location, the city was a stopover and supply point for sea transportation in the Mediterranean, as well as had an important religious place with its churches containing the relics of the holy saints. Lycia was one of the areas in the Eastern Mediterranean where a lot of invasion and piracy activities took place. The geographical location of the Lycian region has made the region an open target for pirates and foreign powers throughout history. Between the end of the $5^{\text {th }}$ century BC and the first half of the $4^{\text {th }}$ century BC was a particularly difficult period in which the Lycian city-states struggled both among themselves and with invading foreign powers. After the conversion of Lycia to the Roman province in $43 \mathrm{AD}$ by Emperor Claudius, the invasion and piracy gradually decreased. The peaceful environment of the region was disturbed by the attacks of the Sassanids at the beginning of the $7^{\text {th }}$ century followed by Arab attacks that lasted for nearly 300 years. It is seen that the coastal cities in particular were affected by these attacks. As a matter of fact, during periods of severe attacks, the retreat of people to safer rural areas of mountains were supported by architectural remnants. The people living in the countryside have built defensive structures on the slopes and important valleys along the coast against the dangers that could arise from the sea. In the Classical and Hellenistic periods, when the attacks were intense, sheltered multi-storey buildings with the appearance of towers became the living place of people engaged in agriculture. Tower farmhouses continued to be used for rural area security during the Roman and Byzantine periods. In addition, during the Sassanid and Arab invasions at the $7^{\text {th }}-9^{\text {th }}$ centuries, many small castles were built for rural security. A series of small castles of Byzantine period were identified during the surveys in the rural area on north of the city of Myra. Byzantine castles are located in the upper part of the Myros valley, stretching from the city of Myra to the Kasaba Plain. The castles, which are connected with each other, overlook the Myra and Kasaba plains and the Myros valley. Certainly, these castles were built to protect both the people living in the mountainous area and the ancient Roman road in the valley. One of these castles is located in the Ayiveliler, which is the subject of this article. In the article, it is aimed to introduce the architectural features of the castle, to evaluate its place and importance in the security of the rural area together with other defensive structures.
\end{abstract}

Structured Abstract: During our surveys in the area, a total of six Byzantine fortress buildings were identified; these include Yılanbaşı, Belören Village Asar Belen Tepe, Karabel Eşekkırı̆̆ı, Göynük Köte

\footnotetext{
${ }^{*}$ Doç. Dr., Ankara Hacı Bayram Veli Üniversitesi, Edebiyat Fakültesi, Sanat Tarihi Bölümü. Assoc. Prof. Dr. Ankara Hacı Bayram Veli University, Faculty of Letters, Department of Art History. ORCID 0000-0001-7173-7120

bulent.isler@hbv.edu.tr Studies, 16(7), 203-220. https://dx.doi.org/10.7827/TurkishStudies.54725

Received/Geliş: 23 November/Kasım 2021

Accepted/Kabul: 27 December/Aralık 2021

Checked by plagiarism software

Published/Yayın: 31 December/Aralık 2021

\author{
CC BY-NC 4.0
}

Cite as/ Atıf: İşler, B. (2021). Bizans Döneminde Myra (Demre) Kenti kırsalında güvenlik: Ayıveliler Kalesi. Turkish 
locality and two in Ayiveliler. Apart from these castles, Myra Castle at the beginning of the Myros valley and Dereağzı Castle at the end of the valley which have not surveyed, are other castles were built in Byzantine period. All of the castles are located on the upper part of the mountains extending parallel to the coast, so that they can see the Mediterranean Sea and the Myros valley.

Ayiveliler Castle is located on a small hill, which is popularly called Kale Hill, in the Ayiveliler locality of Karadağ village, in the town of Kaş. The location of the castle is on the upper part of the Myros Valley, which is approximately $750 \mathrm{~m}$ deep, stretching from Demre to the Kasaba plain. It is closer to Dereağzı Castle, another Byzantine period defensive structure at the end of the valley. The southern wall of the castle facing the valley is ruined, the other walls are preserved in good condition up to $2.5 \mathrm{~m} \mathrm{high}$. It could not be determined how high the castle walls were. However, the absence of bastions supporting the walls indicates that the walls were not very high. Due to the fact that it was established on a rocky and uneven land, there is an $8 \mathrm{~m}$ level difference between the north and south ends of the castle area. Today, the castle area is largely covered with maquis vegetation. There must also be cistern / cellar structures. Although they cannot be detected in the castle area due to maquis vegetation and rubble filling.

The castle has a square plan of $37.30 \times 37.70 \mathrm{~m}$ and covers a total area of $1524 \mathrm{~m}^{2}$. The castle area is divided into two equal parts by a $0.9 \mathrm{~m}$ thick wall extending from the southeast corner to the northwest corner. The northern area of the castle is flatter and there are two buildings adjacent to the northwest and northeast corners. In the southern area, which has a much more rough and rocky structure, no settlements could be detected. The western, northern and eastern walls of the castle are $1.5 \mathrm{~m}$ thick and follow a straight line, while the south wall is $1.1 \mathrm{~m}$ thick and has curves according to the terrain. The western, northern and eastern walls, which are thicker than the south wall, taper by indenting $0.40 \mathrm{~m}$, about $2 \mathrm{~m}$ above the ground inside. This recess was probably created for the watchers to walk on the castle wall. All the walls that make up the outer lines of the castle were built with rough cut stones without the use of mortar to form a very smooth surface. The only entrance to the castle is on the north wall. The two-stage door opening is $1.45 \mathrm{~m}$ wide on the outside and $2.15 \mathrm{~m}$ on the inside. The lintel of the rectangular door, consisting of a monolithic block stone, is in situ. There are windows on both sides of the door.

The building adjacent to the northeast corner of the castle has a rectangular plan with dimensions of $6.90 \times 8.53 \mathrm{~m}$ from the inside and covers an area of $65.88 \mathrm{~m}^{2}$. The southern and western walls of the building, up to $4 \mathrm{~m}$ above the existing floor, are still standing. The interior floor is covered with the rubble of the collapsed walls and maquis vegetation. The entrance to the lower floor of the building is through a door 1.30 $\mathrm{m}$ on the outside and $1.5 \mathrm{~m}$ on the inside, which opens near the western corner of the south wall. The beam slot on the upper part of the western wall indicates that the building had two floors. There is no data on the entrance or architectural features of the second floor of the building. The beam slots on the walls indicate a wooden floor separation. The second floor of the building was probably reached by a wooden staircase. The west and south walls of the building, $0.75 \mathrm{~m}$ thick, were built with coarse cut stones using a lime-sand mixture. The fact that the mentioned walls were built with different thickness and technique than the castle walls indicate the annexation of the building in the second phase of construction.

The building adjacent to the northwest corner of the castle measures approximately $9.05 \times 8.77 \mathrm{~m}$ from the inside and covers a total area of $82.20 \mathrm{~m}^{2}$. The ground floor of the building, which is understood to have two floors, is divided into two parts by a wall in the north-south direction. The $0.9 \mathrm{~m}$ wide door opening in the middle of the wall provides the connection between the two spaces. There is a window opening on the north side of the door. The entrance to the ground floor is through the $1.4 \mathrm{~m}$ wide door located in the middle of the east wall of the building. The floor of the building is filled with the rubble of the collapsed walls up to the upper floor separation. The only data associated with the upper floor of the building is the $1 \mathrm{~m}$ wide door opening on the south wall. The high ground level of the door opening indicates the accessibility to the second floor from the south. The wall thickness and knitting technique of the building are very similar to the building in the northeast corner. The $0.8 \mathrm{~m}$ thick south and east walls of the building were built with coarsely cut stones using lime mortar. Therefore, this building, along with another building, must be added to the castle in a later phase.

The common feature of the six castles we found during our surveys is their small size. The number of buildings that could be residential is limited, and most of them were added at a later stage. It is an interesting feature that the inner floors of the four castles are rocky except Asar Belen Tepe and Yılanbaş1. 
Due to these features, they are suitable structures for the accommodation of a small military unit. These structures were probably only used for temporary shelter, early warning and surveillance during the attacks.

Myra and Dereağzı castles, which are out of our research area, cover a larger area than other castles. Since their walls are higher, the walls of both castles are supported by bastions. In addition, the churches in them were for the use of a large group. Therefore, it is possible to say that Dereağzı and Myra castles were for crowded military units/garrison, and the other six castles were for small military units attached to the garrison.

The main problem of the Ayiveliler Castle and other castle structures in the region is dating. Dereağz1 Castle is dated to the period of Arab attacks between the middle of the $7^{\text {th }}$ century and the end of the $9^{\text {th }}$ century by J. Morganstern, who conducted surveys there in the 1970s. Although the archaeological finds are quite insufficient in dating the castles, the chapel or nearby churches and residential buildings and cross decorated stone artifacts show that the castles were built in the Byzantine period. The castles, which are the subject of research due to historical events, must have been built between the $7^{\text {th }}$ and $9^{\text {th }}$ centuries.

Key words: Art History, Byzantine Art, Rural security, Castle, Myra, Ayıveliler Fortress

Öz: Günümüzde Antalya iline bağlı Demre ilçe merkezini oluşturan Myra, doğuda Phaselis’ten başlayarak batıda Fethiye körfezine uzanan Likya bölgesinin yaklaşık ortasında yer alan antik bir kıyı kentidir. Myra Bizans döneminde yükselişe geçerek 5. yüzyılda Likya bölgesinin dini ve idare merkezi haline gelmiştir. Kent konumu bakımından Akdeniz'deki deniz ulaşımında uğrak ve ikmal noktası olmasının yanısıra Hıristiyanlar için kutsal sayılan azizlerin röliklerini içeren kiliseleriyle dini bakımdan önemli bir yere sahipti. Akdeniz bölgesinde Likya, istila ve korsanlık/haydutluk faaliyetlerinin en yoğun olduğu bölgelerin başındadır. Likya bölgesinin coğrafi konumu tarih boyunca bölgeyi korsanlar ve yabancı güçler için açık bir hedef haline getirir. Özellikle Anadolu'da Pers istilalarının olduğu, M.Ö. 5. yüzyıl sonu ile M.Ö. 4. yüzyıl ilk yarısı Likya kent devletlerinin hem kendi aralarında hem de işgalci dış güçlerle mücadele ettikleri zorlu bir dönemdir. Likya bölgesinin MS. 43 yılında İmparator Cladius'un emriyle Roma eyaleti haline gelmesinden sonra istila ve korsanlık faaliyetlerinin giderek azaldığı görülür. Bölgenin huzur ortamı 7. yüzyıl başlarında Sasaniler ardından 300 yıla yakın süren Arap saldırılarıyla bozulur. Söz konusu saldırılardan özellikle kıyı kentlerin oldukça çok etkilendiği görülmektedir. Nitekim saldırıların yoğun olduğu dönemlerde, insanların daha güvenli olan dağlık kırsal alana çekildikleri mimari kalıntılarla desteklenir. Kırsalda yaşayan halk denizden gelebilecek tehlikelere karşı, kıyı boyunca uzanan yamaçlara ve önemli geçitlere savunma ve gözetleme amaçlı yapılar oluşturmuşlardır. Saldırıların yoğun olduğu Klasik ve Helenistik dönemlerde kule görünümlü korunaklı çok katlı binalar, tarımla uğraşan insanların yaşam yeri olmuştur. Kule çiftlikler Roma ve Bizans döneminde kullanılmakla birlikte 7.-9. yüzyıllardaki Sasani ve Arap istilaları zamanında ek olarak çok sayıda küçük kale inşa ederek kırsal alanın güvenliğini sağlanmıştır. Myra kentinin kuzeyindeki kırsal alanda yürütmekte olduğumuz yüzey araştırmalarında Antik dönemden kalma kule çiftlik evler dışında Bizans döneminde inşa edilmiş bir dizi küçük kale tespit edilmiştir. Bizans dönemi kaleleri özellikle Myra kentinden Kasaba ovasına uzanan, yaklaşı $20 \mathrm{~km}$ uzunluğundaki vadinin üst kesimlerinde, denizi ve vadiyi görecek biçimde konumlanmıştır. Kaleler kuşkusuz hem dağlık alanda yaşayan halkı hem de vadinin içindeki eski Roma yolunu korumak amaçlı inşa edilmiştir. Bu yapılardan biri makalenin konusunu oluşturan Ayıveliler mevkiinde bulunan kaledir. Makalede kalenin mimari özelliklerinin tanıtılması, diğer savunma yapılarıyla birlikte kırsal alanın güvenliğindeki yeri ve öneminin değerlendirilmesi amaçlanmaktadır.

Anahtar Kelimeler: Sanat Tarihi, Bizans sanatı, Kırsal güvenlik, Kale, Myra, Ayıveliler Kalesi

\section{Giriş}

Günümüzde Antalya iline bağlı Demre ilçe merkezini oluşturan Myra, doğuda Phaselis’ten başlayarak batıda Fethiye körfezine uzanan Likya bölgesinin yaklaşık ortasında yer alan antik bir kıyı kentidir. Myra Bizans döneminde yükselişe geçerek 5. yüzyılda Likya bölgesinin dini ve idare merkezi haline gelmiştir. Kent konumu bakımından Akdeniz'deki deniz ulaşımında uğrak ve ikmal noktası olmasının yanısıra Hıristiyanlar için kutsal sayılan azizlerin röliklerini içeren kiliseleriyle dini bakımdan önemli bir yere sahiptir. 
Myra kentinin bulunduğu Likya bölgesi, kıyıya paralel uzanan Toros dağlarının denizin hemen gerisinden başladığından, nehirlerin oluşturduğu alüvyon ovalar dışında kıyı boyunca düz alanlar oldukça kısıtlıdır. Dağlar bölgenin kuzeyiyle sahil kesimi arasındaki ulaşımı olumsuz etkilemekle birlikte, ekim ve yerleşim için küçük ova ve havzaları içermesi bakımından avantajlar da sunuyordu. Nitekim dağlık yüksek kesimlerde engebeli araziye dağılmış halde çok sayıda küçük yerleşim birimi bulunmaktaydı. Dağlı alanlardaki bu yerleşimler, korunaklı konumları sayesinde, kıyılarda, M.Ö. 1. yüzyıldan başlayarak giderek artan derecede meydana gelen salgın hastalıklar, korsanlık faaliyetleri ve istilaların uzağında izole bir yaşam sürdürüyordu.

Akdeniz bölgesinde Likya korsanlık ve haydutluk faaliyetlerinin en yoğun olduğu bölgelerin başındadır. Bizans döneminde önce Sasaniler, ardından Araplar, İtalyan gemicileri ve Türklerin düzenli akınlarıyla kıyı bölgeleri yakılıp yıkılıyor ve yağmalanıyordu. Kapsamlı savunma duvarlarından yoksun olan kıyı kentleri istila ve korsanlık faaliyetlerinden korunmada oldukça yetersizdi. Geç Antik Çağ'da (M.S. 2.-6. yüzyıllar) halkı yavaş yavaş kıyı kentlerini terk ederek daha güvenli olan iç kesimdeki kırsal alanlara yönelmişti. Nitekim bölgede bulunan kalıntılar Bizans döneminde halkın büyük bölümünün kıyının gerisindeki dağlık alanlarda yaşadığını göstermektedir. Korunmak amaçlı olarak da Likya bölgesinin sahili boyunca, düşman gemilerinin çok uzaklardan görülebilmelerini sağlayan gözetleme kuleleri ve tahkimli kaleler oluşturuldu. Söz konusu kule ve kaleler özellikle kıyının gerisindeki kırsal alanda yaşayan halkın güvenliği için hayati öneme sahipti.

Myra kentinin kuzeyinde yürütmekte olduğumuz yüzey araştırmalarında Antik dönemden kalma kule çiftlik evler dışında Bizans döneminde inşa edilmiş bir dizi küçük kale tespit edilmiştir ${ }^{1}$. Bizans dönemi kaleleri özellikle Myra kentinden Kasaba ovasına uzanan, yaklaşık 20 $\mathrm{km}$ uzunluğundaki Myros vadisinin üst kesimlerinde, denizi ve vadiyi görecek biçimde konumlanmıştır (Resim 1). Kaleler kuşkusuz hem dağlı alanda yaşayan halkı hem de vadinin içindeki eski Roma yolunu korumak amaçlı inşa edilmiştir. Bu yapılardan biri makalenin konusunu oluşturan Ayıveliler mevkiinde bulunan kaledir. Makalede kalenin mimari özelliklerinin tanıtılması, diğer savunma yapılarıyla birlikte kırsal alanın güvenliğindeki yeri ve öneminin değerlendirilmesi amaçlanmaktadır. Konuyla ilgili olarak bölgedeki tüm kale ve gözetleme kulelerini kapsayan daha ayrıntılı bir yayın çalışmamız devam etmektedir.

\footnotetext{
1 Kültür ve Turizm Bakanlığı, Kültür Varlıkları ve Müzeler Genel Müdürlüğü'nün izni ile sürdüğümüz yüzey araştırmaları, Koç Üniversitesi, Suna\&İnan Kıraç Akdeniz Medeniyetleri Araştırma Merkezi (AKMED) tarafından KU_AKMED_2018P.1012 numaralı proje kapsamında desteklenmiştir.
} 


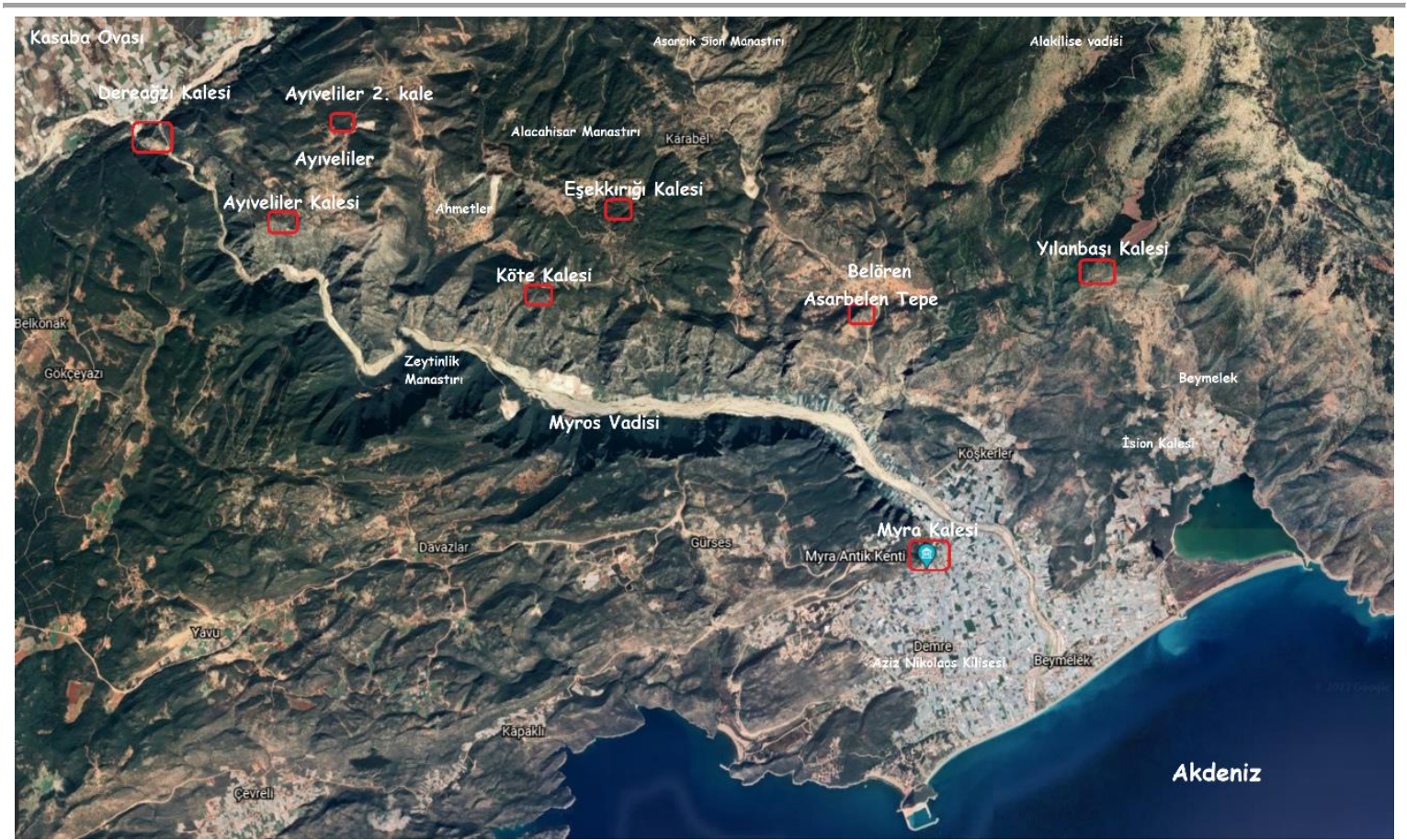

Resim 1: Ayıveliler kalesi ve makaleye konu Bizans kalelerini gösteren hava fotoğrafı (Kaynak: Google Earth)

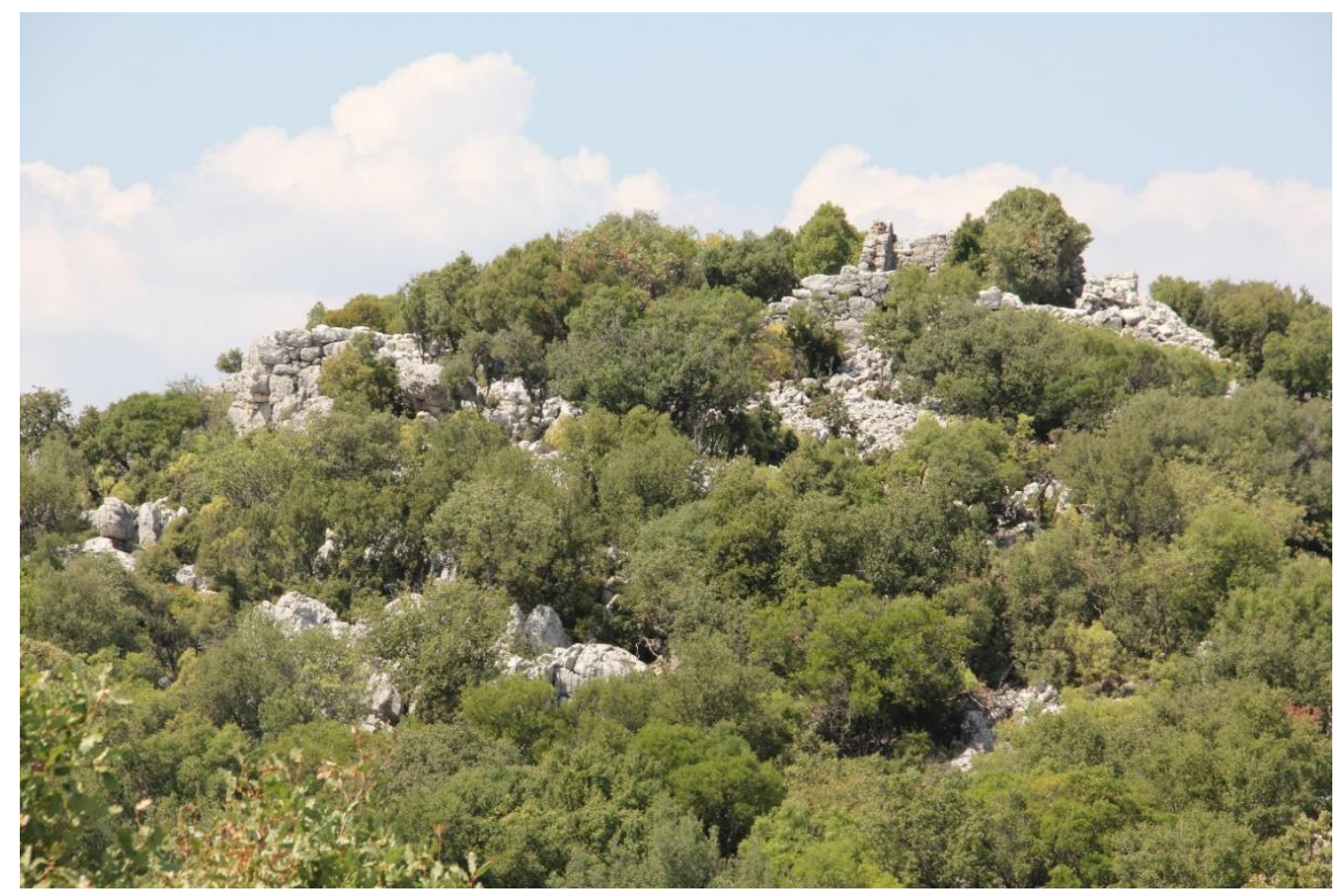

Resim 2: Ayıveliler kalesinin doğudan genel görünümü 


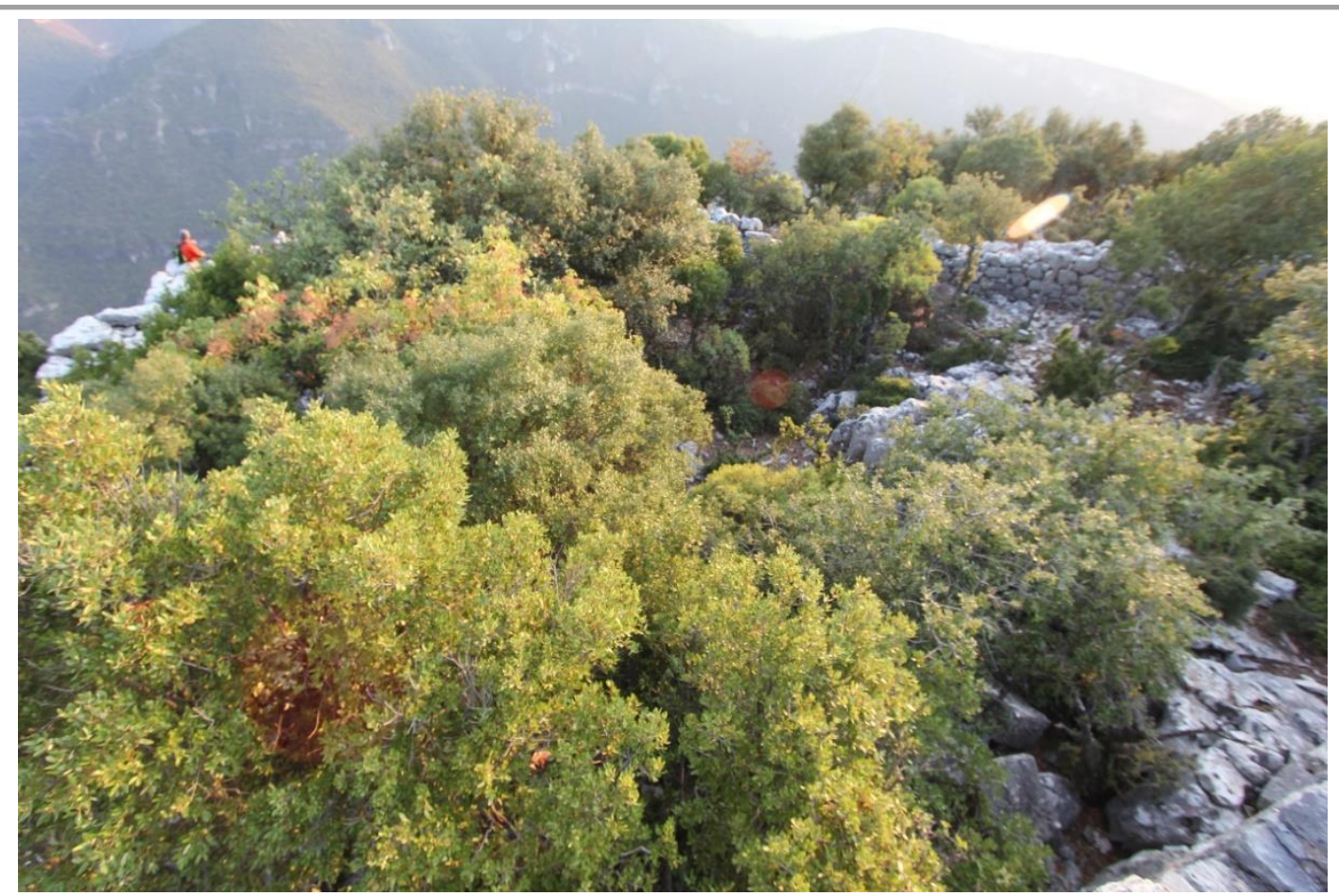

Resim 3: Ayıveliler kalesinin içinin kuzeyden genel görünümü

\section{Ayıveliler Kalesi:}

Kalenin özgün adı bilinmediği için yakınında yer alan modern yerleşimden dolayı Ayıveliler kalesi olarak adlandırılmıştır. Yapı, Kaş ilçesine bağlı, Karadağ köyü Ayıveliler mevkiinde, halk arasında Kale Tepe olarak adlandırılan küçük bir yükseltinin üstünde yer alır (Resim 2). Kale, Demre'den Kasaba ovasına uzanan yaklaşık $750 \mathrm{~m}$ derinliğindeki Myros vadisinin üst kısmında, tüm vadiyi görebilecek biçimde konumlanmıştır. Konum olarak vadinin bitimindeki diğer bir Bizans dönemi savunma yapısı olan Dereağzı kalesine daha yakındır (Resim 1).

Kalenin vadiye bakan güney duvarının bir kısmı yıkık olmakla birlikte diğger duvarları 2,5 m yüksekliğe ulaşan alt bölümü iyi durumda korunmuştur. Kale duvarlarının özgün yüksekliği tespit edilememiştir. Ancak duvarlarda, duvarları destekleyen burçların olmaması duvarların çok yüksek olmadığını düşündürmektedir. Kayalık ve engebeli bir araziye kurulmuş olmasından dolayı kale alanının kuzey ile güney ucu arasında 8 metrelik kot farkı vardır. Bugün kale alanı büyük ölçüde maki bitki örtüsüyle kaplıdır (Resim 3). 


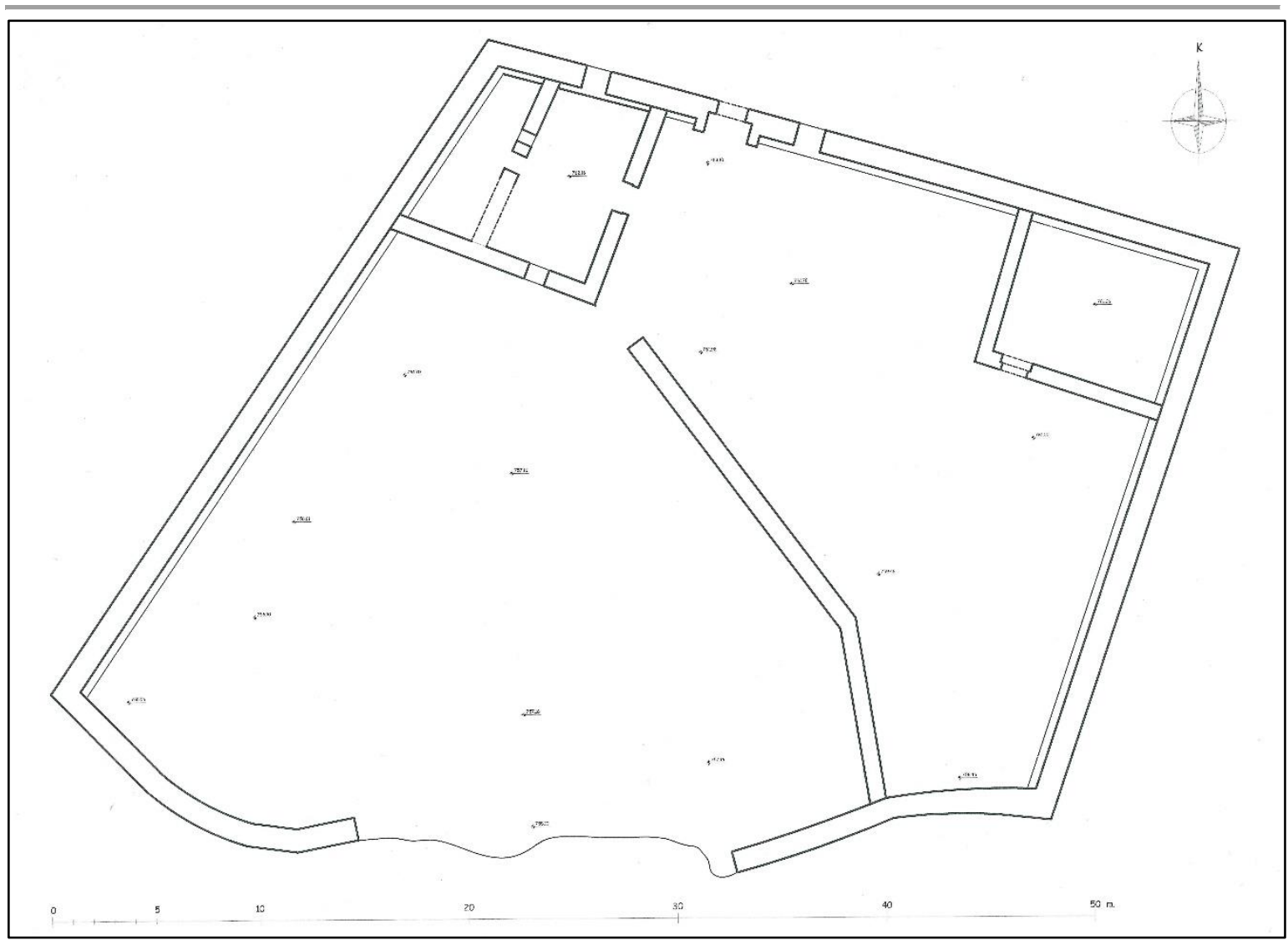

Resim 4: Ayıveliler kalesinin planı (İşler 2020)

Kale 37.30x37.70 m ölçülerinde yaklaşık kare planlı olup toplamda $1524 \mathrm{~m}^{2}$ lik alanı kaplamaktadır (Resim 4). Kale alanı güneydoğu köşeden kuzeybatı köşeye uzanan $0.9 \mathrm{~m}$ kalınlığındaki duvarla, iki eşit bölüme ayrılmıştır. Duvarın kuzeybatı ucunda kalenin kuzeyi ile güneyini bağlayan bir kapı açıklığı yer alır. Kalenin kuzey alanı daha düz olup içinde kuzeybatı ve kuzeydoğu köşelerine bitişik halde iki bina bulunmaktadır. Çok daha engebeli ve kayalık bir yapıya sahip olan güney alanında herhangi bir yapılaşma tespit edilememiştir. Kalenin $1.5 \mathrm{~m}$ kalınlığındaki batı, kuzey ve doğu duvarları düz bir hat izlemekte, $1.1 \mathrm{~m}$ kalınlığındaki güney duvarı ise arazi yapısına göre kavis yapmaktadır. Güney duvara göre daha kalın olan batı, kuzey ve doğu duvarları içte zeminden yaklaşık $2 \mathrm{~m}$ yukarıda, $0.40 \mathrm{~m}$ içe girinti yaparak incelir. Bu girinti olasılıkla gözcülerin kale duvarı üzerinde ulaşımı için oluşturulmuştur. Kalenin duvarlarının ne kadar yükseldiği veya duvarların mazgallı olup olmadığı belirlenememiștir. Kalenin dıș hatlarını oluşturan tüm duvarları kaba yonu taşlarla harç kullanılmadan oldukça düzgün yüzey oluşturacak biçimde örülmüştür.

Kaleye tek giriş kuzey duvarındaki kapı açıklı̆ından sağlanmaktadır. İki kademeli olan kap1 açıklı̆̆ dışta $1.45 \mathrm{~m}$, içte $2.15 \mathrm{~m}$ genişliğindedir. Dikdörtgen biçimli kapının yekpare blok taştan oluşan lentosu in situdur. Kapının iki yanında birer pencere açıklığının olduğuna dair izler görülür (Resim 5). Pencere açıklıklarının tabanı yaklaşık kapı üst seviyesinden başlamaktadır. 0.90 m genişliğindeki pencere açıklıklarının yüksekliği, duvarlar yıkık halde olmasından dolayı tespit edilememiştir. 


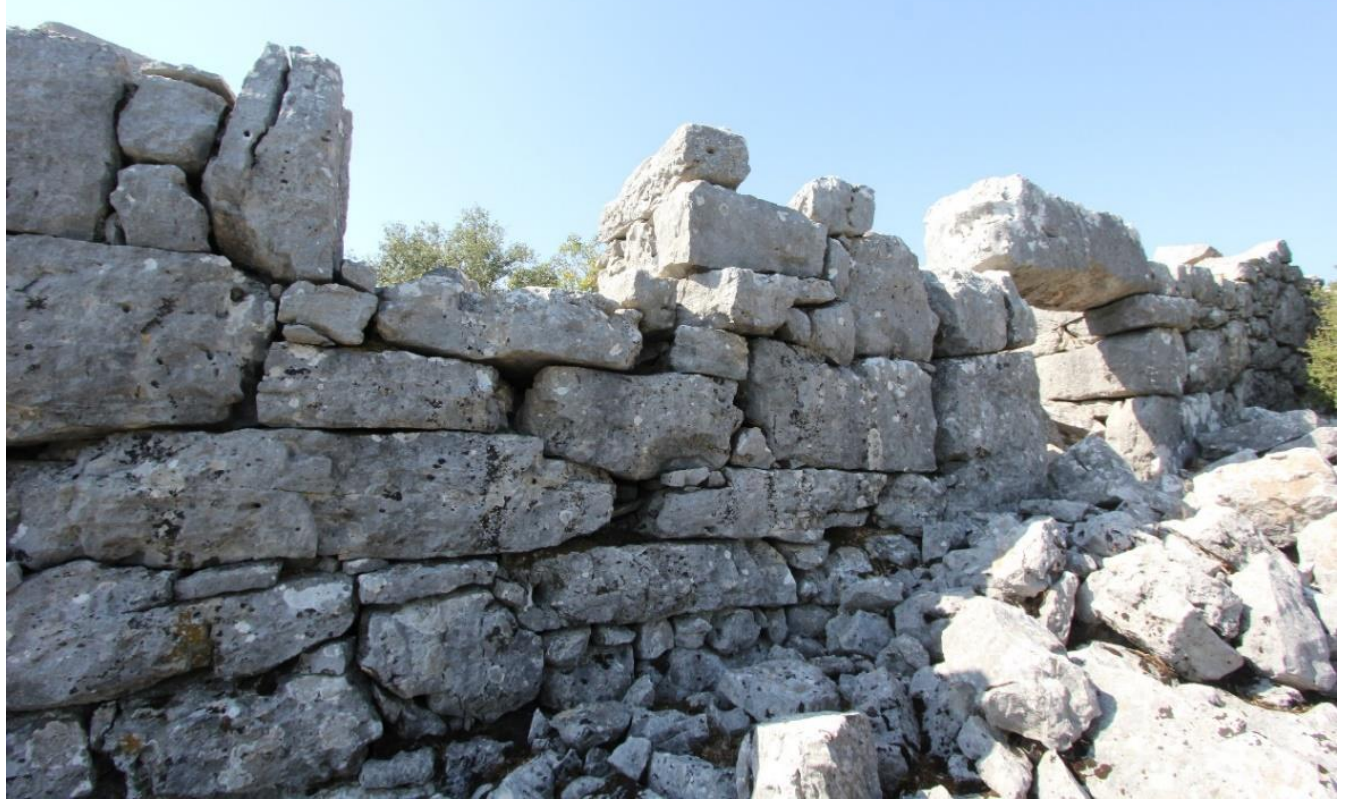

Resim 5: Ayıveliler kalesi kuzey duvarı, kapı ve pencere açıklıklarının görünümü

Kalenin kuzeydoğu köşesine bitişik olan bina içten 6.90x8.53 m doğu-batı doğrultusunda dikdörtgen planlı olup $65.88 \mathrm{~m}^{2}$ alanı kaplamaktadır. Yapının güney ve batı duvarı mevcut zeminden 4 m yüksekliğe kadarki bölümü ayaktadır (Resim 6). İç zemini yıkılan duvarların molozu ve maki bitki örtüsüyle kaplıdır. Yapının alt katına giriş güney duvarının batı köşesi yakınına açılan dışta $1.30 \mathrm{~m}$ içte $1.5 \mathrm{~m}$ genişliğindeki kapıdan sağlanır. İki kademeli olan kapı dışta dikdörtgen biçiminde içte ise yuvarlak kemerlidir. İçteki kemer dışa kör kemer olarak yansıtılmıştır. Kap1 açıklığı dışında mevcut duvarlarda pencere açıklığı bulunmamaktadır. Batı duvarı üst kısmındaki kiriş yuvası yapının iki katı olduğunu göstermektedir. Yapının ikinci katının giriş yeri veya mimari özellikleri hakkında veri bulunmaz. Duvarlardaki kiriş yuvaları ahşap bir kat ayrımının olduğunu göstermektedir. Yapının ikinci katına da olasılıkla ahşap bir merdivenle ulaşılmaktaydı.

Binanın $0.75 \mathrm{~m}$ kalınlığındaki batı ve güney duvarı kaba yonu taşlarla kireç-kum karışımı harç kullanılarak örülmüştür. Söz konusu duvarların kale duvarlarından farklı kalınlık ve teknikte inşa edilmesi, binanın ikinci bir yapım evresinde eklendiğini göstermektedir.

Kalenin kuzeybatı köşesine bitişik yapı ise içten yaklaşı $9.05 \times 8.77$ m ölçülerinde, toplam $82.20 \mathrm{~m}^{2}$ lik alanı kaplamaktadır. İki katlı olduğu anlaşılan yapının zemin katı, kuzey-güney doğrultusundaki bir duvarla iki bölüme ayrılmıştır (Resim 7). Duvarın ortasındaki $0.9 \mathrm{~m}$ genişliğinde kapı açıklığı iki mekan arasındaki bağlantıyı sağlar. Kapının kuzey yanında bir pencere açıklığ 1 bulunmaktadır. Zemin kata giriş yapının doğu duvarı ortasında bulunan $1.4 \mathrm{~m}$ genişliğindeki kapıdan sağlanmaktadır. Yapının zemini, üst kat ayrımına kadar yıkılan duvarların molozu ile doludur.

Yapının duvarlarının büyük kısmının yıkık halde olması üst katının mimari özelliklerinin tespit edilmesini güçleştirir. Yapının üst katıyla ilişkili tek veri güney duvarda yer alan $1 \mathrm{~m}$ genişliğindeki kapı açıklığıdır. Kapı açıklığının zemin seviyesinin yüksek olması ikinci kata güneyden giriş sağlandığını göstermektedir.

Binanın duvar kalınlığı ve örgü tekniği kuzeydoğu köşedeki binanınki ile çok benzer özellikler göstermektedir. Binanın 0.8 m kalınlığındaki güney ve doğu duvar kaba yonu taşlarla 
kireç harcı kullanılarak örülmüştür. Dolayısıyla bu bina da diğer bina ile birlikte sonraki bir evrede kalenin içine eklenmiş olmalıdır.

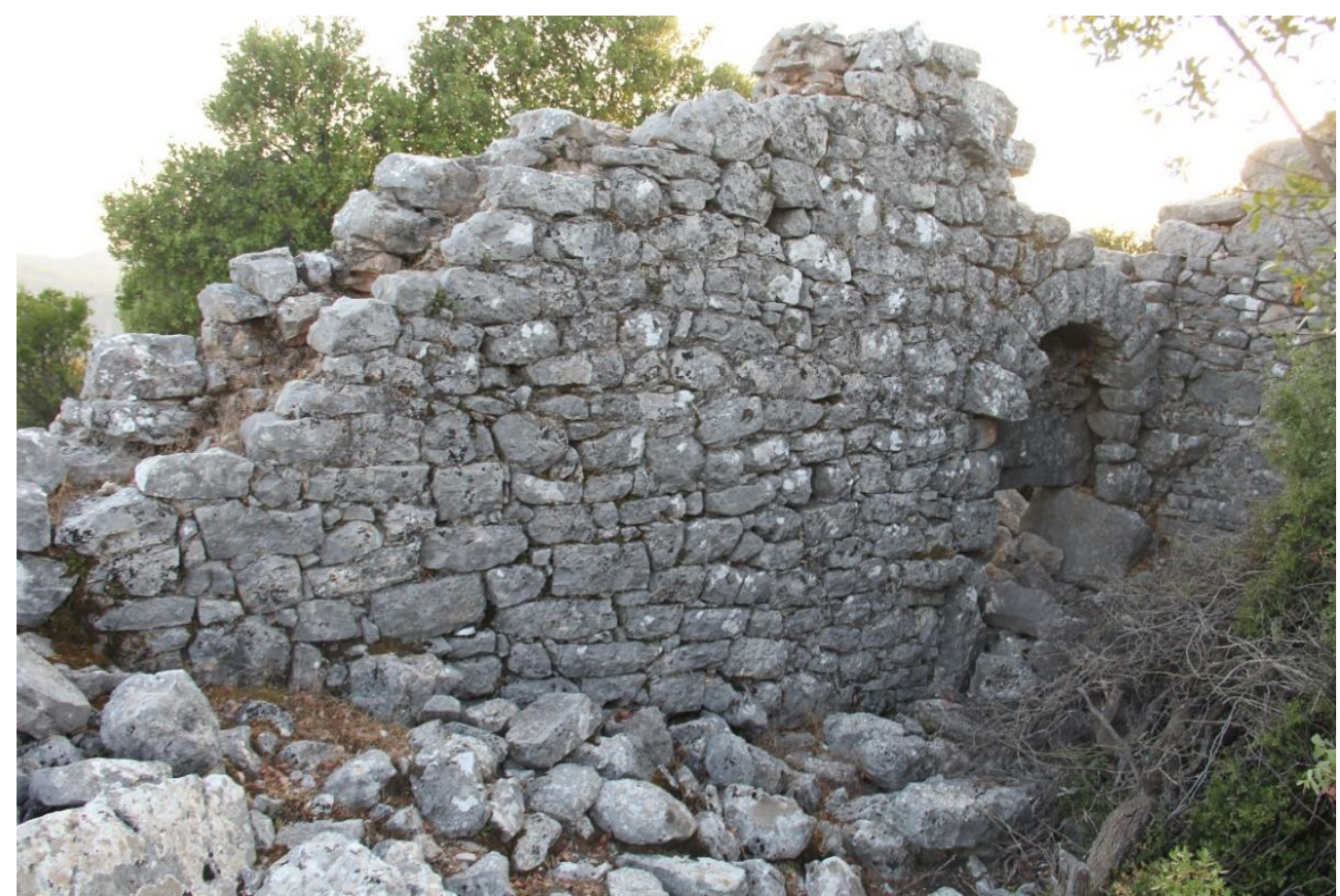

Resim 6: Ayıveliler kalesi, kuzeydoğu köşedeki binanın güney duvarının içten görünümü

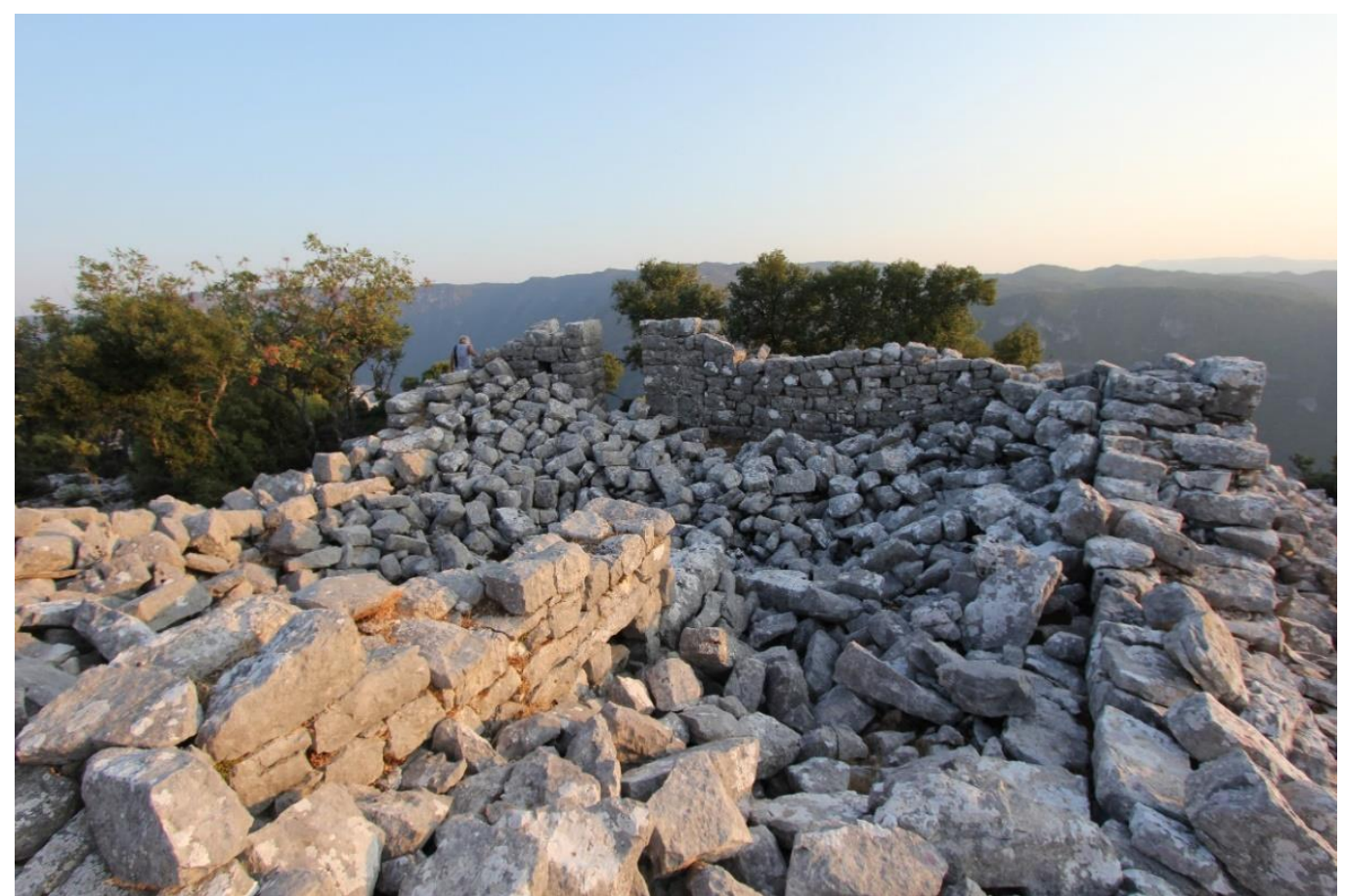

Resim 7: Ayıveliler kalesi, kuzeybatı köşedeki binanın kuzeyden genel görünümü 
Kale alanında, maki bitki örtüsü ve moloz dolgudan dolayı tespiti yapılamamakla birlikte mutlaka sarnıç/mahsen yapıları da olmalıdır. Dağlık alanda doğal su kaynaklarının olmaması nedeniyle insanların ve hayvanların su ihtiyacı sarnıçlardan karşılanmıştır. Kışın binaların çatısından toplanan yağmur suyu, ana kayanın oyulmasıyla oluşturulmuş olan yeraltı mahzenlerinde biriktirilmiştir. Sarnıçlar tamamen yeraltında, yukarıdan aşağıya doğru armut biçiminde genişleyen biçimde inşa edildiklerinden çoğu zaman yerlerini bulmak zordur. Dağlık alandaki her binanın kendine ait bir veya daha fazla sarnıcı bulunmaktadır. Özellikle kale işlevli yapılarda sarnıçlar zaruri bir ihtiyaçtır.

\section{Değerlendirme:}

Ayıveliler kalesi Kasaba ovasından Myra antik kentine ulaşan Myros vadisinin üst kısmında yer alır. Vadi aynı zamanda kıyıya paralel uzanan dağların ardındaki ovalık alan ile kıyı şeridi arasındaki bağlantıyı sağlar. Vadi tabanında Myros nehrini takip eden Roma yolu bulunur. $\mathrm{Bu}$ yol yardımıyla iç bölgelerde yetiştirilen ürünlerin kıyıya ulaştırıldığı ve buradan diğer Roma kentlerine ihraç edildiği bilinir. Dolayısıyla Ayıveliler kalesi bu yolun güvenliğini sağlamak için gözetleme amaçlı inşa edilmiş olmalıdır. Kale alanının oldukça küçük ve kayalık olmasından dolayı kale sadece küçük bir askeri birlik tarafından kullanılmış olmalıdır.

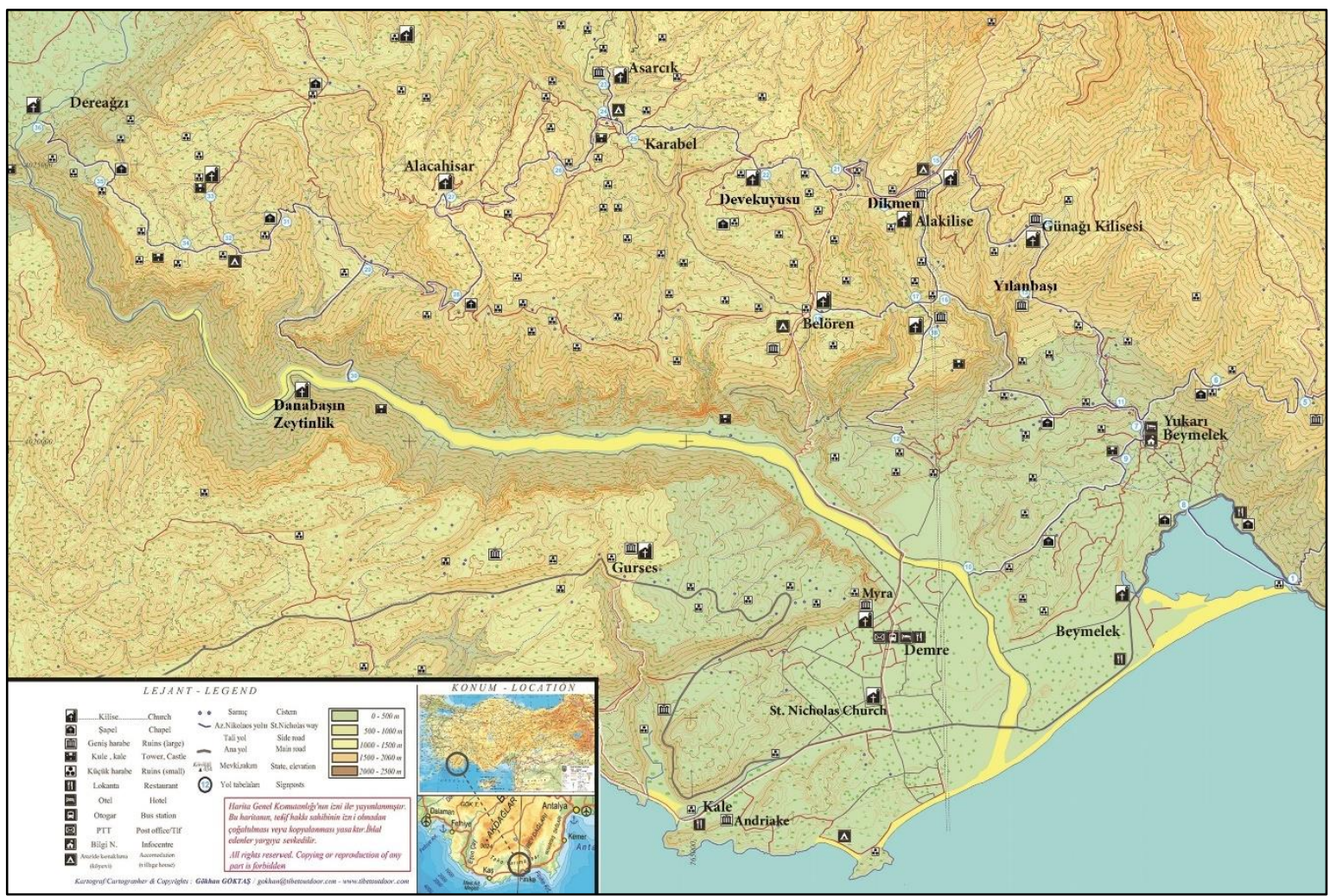

Resim 8: Myra (Demre) kırsalındaki Bizans dönemi kalelerini ve yerleşimlerini gösteren harita

(Kaynak: Kate Clow)

Kalenin duvar tekniği ve mimari özellikleri Bizans döneminde inşa edildiğini göstermektedir. Bölgede yürüttügümüz yüzey araştırmalarında Yılanbaşı, Belören Köyü Asar Belen Tepe, Karabel Eşekkırığı, Göynük Köte mevkiinde ve Ayıveliler'de iki olmak üzere toplam altı Bizans dönemine tarihlendirilen kale yapısı tespit edilmiştir (Resim 1, 8). Bu kaleler dışında, yüzey araştırması kapsamında olmayan Myros vadisinin başındaki Myra kalesi ve vadinin sonundaki Dereağzı kalesi Bizans döneminde inşa edildiği bilinen diğer kalelerdir. Kalelerin 
tamamı kıyıya paralel uzanan dağların üst kısmında Akdeniz’i ve Myros vadisini görecek biçimde konumlanmıştır.

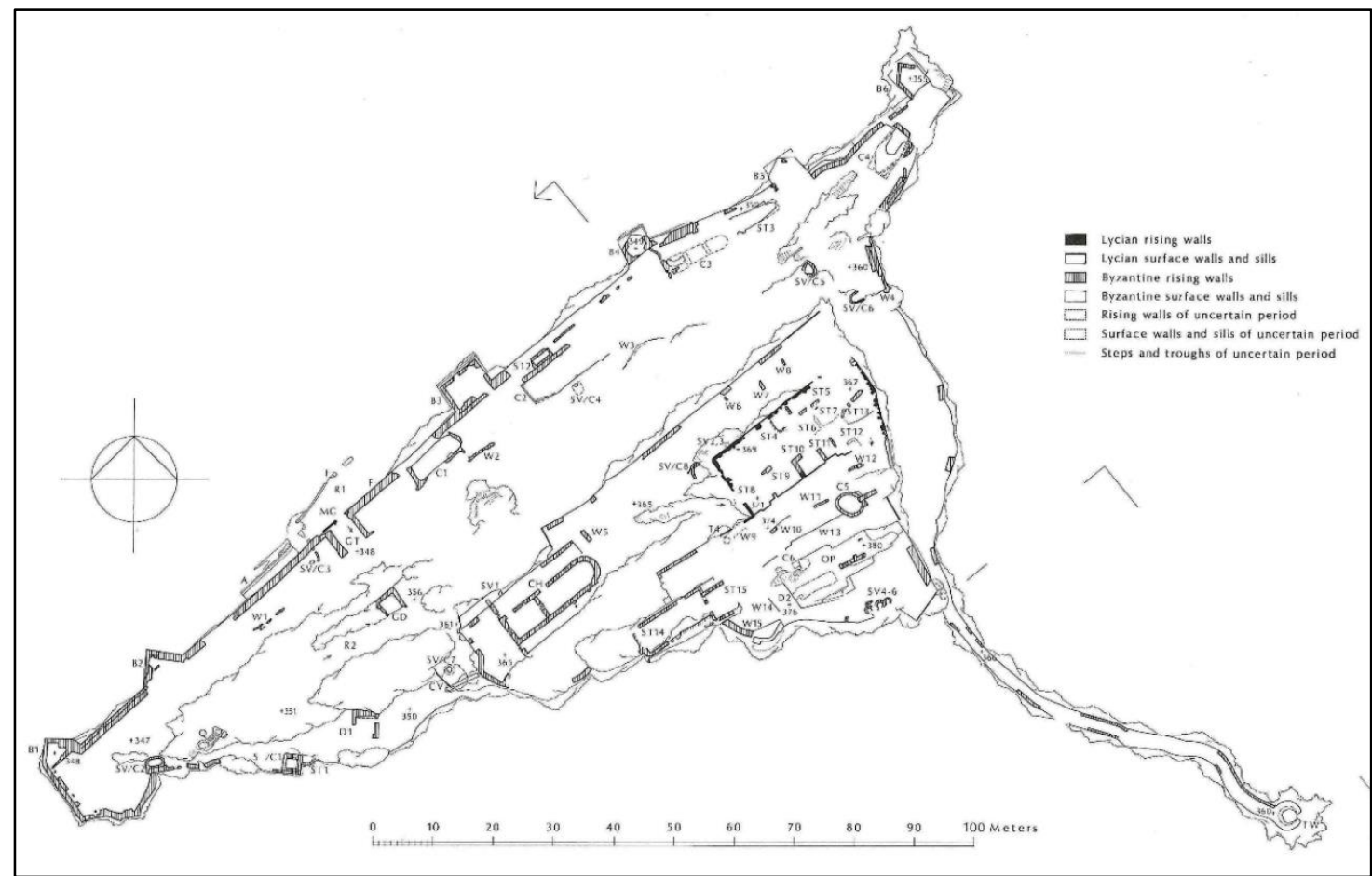

Resim 9: Dereağzı kalesinin planı (Wurster 1993)

Myra antik kentinin yaklaşık $20 \mathrm{~km}$ kuzeybatısında yer alan Dereağzı kalesi, Myros vadisinin girişinde, Kasaba ve Karadağ çayının birleştiği noktada yüksekçe bir tepe üzerinde konumlanır. Kaleden başta Kasaba ovası ve Myros vadisi olmak üzere geniş bir alanı kontrol eder. Seramik buluntularına göre kalenin geçmişinin M.Ö. 9. yüzyıla kadar geri gittiği anlaşılır. Kaya mezarları ve mimari kalıntılar Klasik dönemde, M.Ö. 5. yüzyı1 sonu-M.Ö. 4. yüzyıl başında burada bir yerleşimin olduğunu gösterir. Bizans döneminde 5. yüzyılda, antik yapıların taşları kullanılarak bir kilise inşa edilmiştir. Arap saldırıları sırasında 7.-9. yüzyıllarda kale alanının genişletilerek duvarlarının yeniden inşa edildiği düşünülür (Morganstern 1980, s. 201-220). 60 m uzunluğunda, güneyde $41.80 \mathrm{~m}$ kuzeyde $49.30 \mathrm{~m}$ genişliğinde alanı kaplayan kalenin $1.90 \mathrm{~m}$ kalınlığındaki sur duvarları yer yer burçlarla desteklenmiştir (Resim 9). Kaleye giriş kuzey duvardan tek kapı ile sağlanır. Kayalık bir yapıya sahip olan kale alanı ayrı duvarlara sahip üç kademeli bir düzenlemeye sahiptir. En üst kısımda/akropolde üç nefli kilise yer alır. Kilisenin içinde olasılıkla 9. yüzyılda küçük bir şapel inşa edilmiştir. Kilise dışında kalenin içinde depolama, sarnıç ve bazı konut yapılarına ait temeller izlenir. 


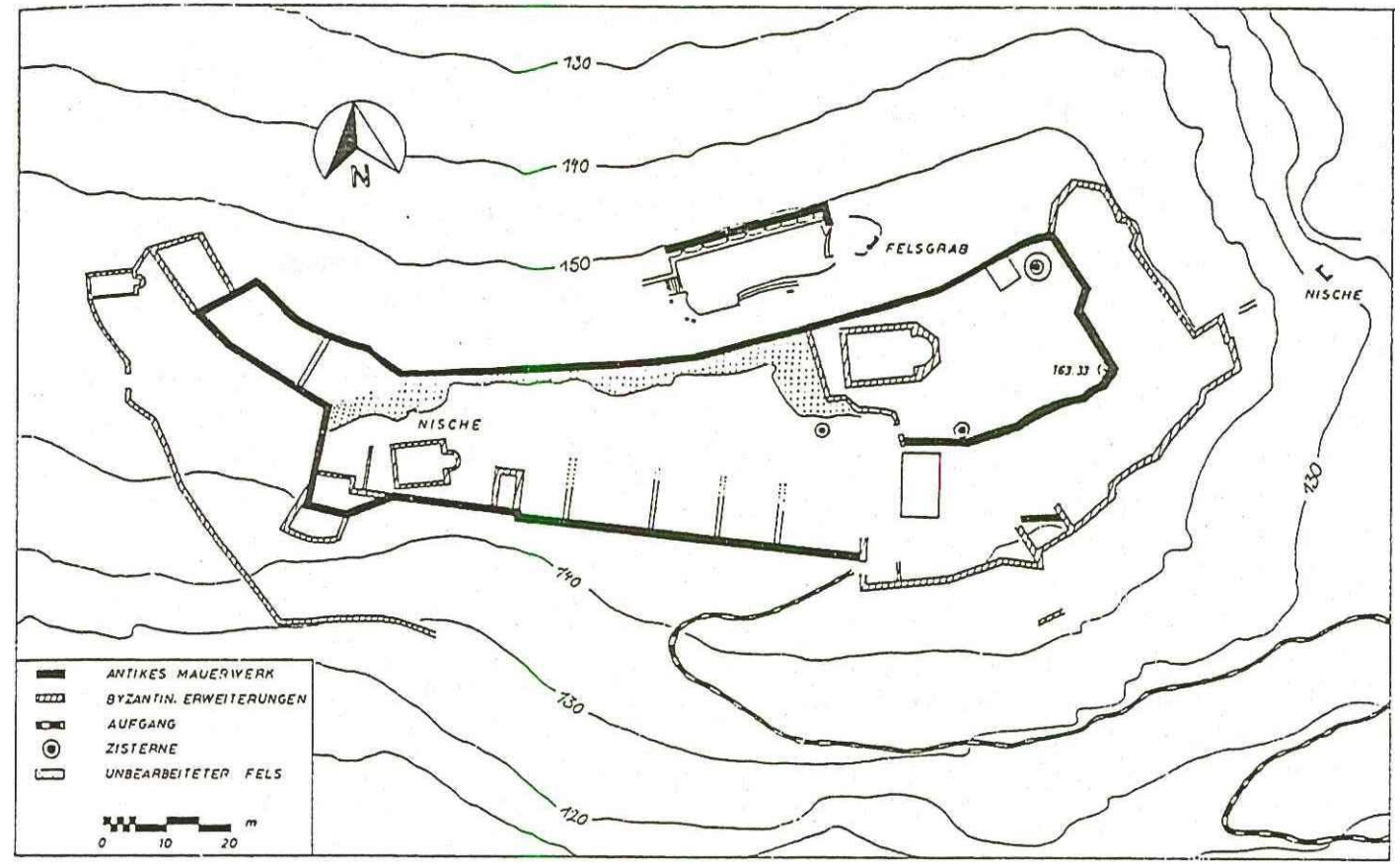

Resim 10: Myra kalesinin planı (Borchhardt 1975)

Myra kalesi, Myros vadisinin ovayla buluştuğu, güneydoğu ucundaki tepenin zirvesini kaplar. Geçmişi Klasik döneme (M.Ö. 5. yüzyıl) kadar geri giden kalenin alanı, Bizans döneminde inşa edilen duvarlarla genişletilmiştir. Duvarlarla içi iki bölüme ayrılan kale, doğu-batı doğrultusunda uzanan 160x50 m ölçülerinde bir alanı kaplamaktadır (Resim 10). Kaleye güney duvarda bulunan bir kapı açıklığından ulaşılır. Girişin hemen kuzeydoğusunda, bir tapınak ya da anıt mezara ait olabilecek podyum ile batıda bir kilise yapısı bulunur. Kısmen kayalık olan zeminde tanımlanamayan yapılara ait bazı duvar kalıntıları görülmektedir. Ayrı bir duvarla çevrili olan iç bölümde bir kilise ile sarnıç yer almaktadır. İki kilisesi bulunan kalenin Bizans döneminde yoğun olarak kullanıldığı anlaşılır (Borchhardt, 1975, s. 45-47; Çevik, 2015, s. 365-366).

Beymelek köyünün kuzeyindeki yamaçta bulunan Yılanbașı kalesi, Helenistik dönem bir kule yapısının Bizans döneminde genişletilmesiyle oluşturulmuştur. Güneydoğu yönünde bir kap1 açıklığıyla ulaşılan kale alanında, oldukça tahrip olmuş halde üç konut yapısı ile konutlar arasında küçük boşluklar gözlenir. Kalenin batı duvarının dışında iki konut yapısı ile doğu ve güney yanında, ana kayaya oyularak oluşturulmuş iki büyük sarnıç bulunur. Batı dıştaki konutlardan birinin kapısının lentosunun ön yüzünde üç haç kabartması yer alır. Dört kolu eş haç kabartmaları birer daire içine alınmıştır. Kalenin $50 \mathrm{~m}$ kadar güneyinde 5. yüzyıl sonu-6. yüzyıl başlarında inşa edilmiş olması gereken üç nefli bazilikal planlı bir kilise bulunur. Kilise içinde bulunan üzerinde kartal ve haç kabartmaları yer alan ambon ya da altar masasına ait olabilecek levhalar, akantus yapraklarıyla bezenmiş sütun başlıkları, haç kazımalarla süslenmiş lentolar kaliteli işçilikleriyle dikkat çeker. Kilise dışında kalenin etrafında birkaç konut, bir şarap işliği, yedi Roma dönemi lahdi ve birkaç sarnıç görülür. 


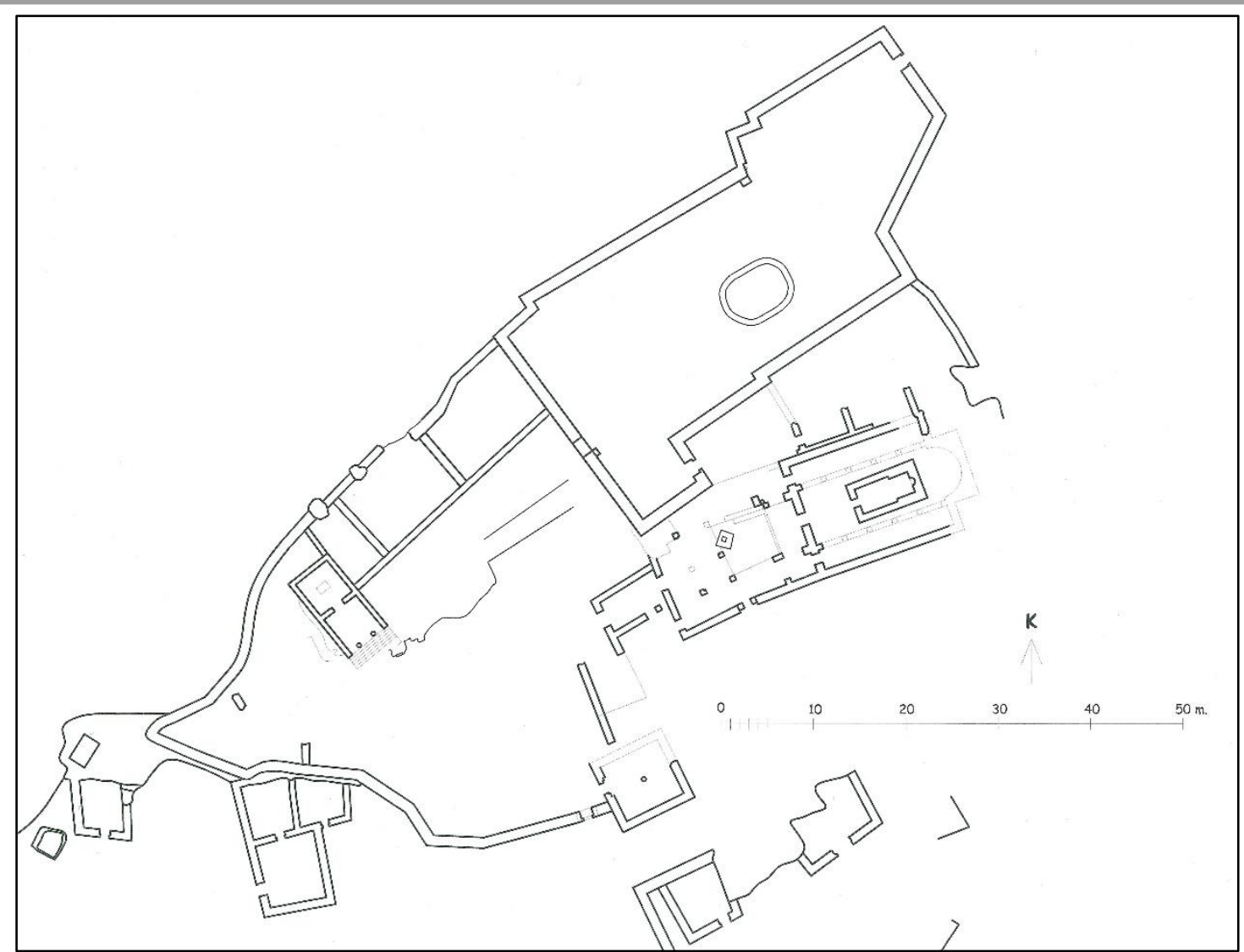

Resim 11: Belören köyü, Asar Belen Tepe'de bulunan Bizans kalesinin planı (çizim: İşler 2019)

Belören köyü Asar Belen Tepe'de yer alan kale de eski bir kule yapısının genişletilmesiyle oluşturulmuştur. Duvar örgü tekniği ve yakınında bulunan seramikler kule yapısının Klasik dönemde (MÖ. 5. yüzyll) inşa edildiğini göstermektedir. 10.60x9.60 m ölçülerinde kuzey-güney doğrultusunda dikdörtgen planlı olan yapıya giriş doğu duvarına açılan kapidan sağlanmıştır. Kulenin batısına MÖ. 2. yüzyılda bir tapınak eklenmiştir. Bizans döneminde kulenin, kuzey ve doğu duvarı kaldırılmış, batı ve güney duvarı kullanılarak çok daha geniş alanı kaplayan bir kale inşa edilmiştir. Bizans kalesi, tepenin zirvesinde, doğu-batı doğrultusunda yaklaşı $52 \times 29 \mathrm{~m}$ ölçülerinde toplam $1.178 \mathrm{~m}^{2}$ alanı kaplamaktadır (Resim 11). Duvarlarının $2.5 \mathrm{~m}$ yüksekliğine kadarki kısmı sağlam haldeki kalenin içi düzgün bir yüzeye sahiptir. Yakın zamana kadar çobanların ağılı olarak kullanılan kale alanı içinde günümüzde bir sarnıç dışında başka yapı kalıntısına rastlanmaz. Ana kayaya oyularak oluşturulan, yaklaşık $5 \mathrm{~m}$ derinliğindeki sarnıcın üst kısmı yıkıktır. Kalenin batı duvarında, sonradan kapatılmış olan kapı açıklığının izi görülebilmektedir. Kalenin güneyinde üç nefli bazilikal planlı bir kilisenin temelleri bulunmaktadır. Kilise içindeki taş eserlerinin motiflerin özellikleri ve işleme tekniği yapıyı 5. yüzyıl sonlarına tarihlendirmeyi olanaklı kılar. Kalenin bulunduğu tepenin eteklerinde, kısmen ana kayaya oyulmuş çok sayıda konut yapısı, sarnıç, tarımsal üretime yönelik işlik ile altmış kadar lahit tipi mezar tespit edilir.

Belören köyüne bağlı Karabel mahallesinin Eşekkırı̆̆ı mevkiinde yer alan Bizans kalesi, diğer kalelere göre daha iç kısımda olmakla birlikte bulunduğu konumdan tüm Demre (Myra) sahili görülebilmekdedir. Kale tepenin zirvesinde, $50 \mathrm{~m}$ çapında dairesel bir alanı kaplamaktadır. Kale alanı kayalık bir yapıya sahip olup bina yapılabilecek düz alan oldukça kısıtlıdır. Nitekim kale alanı içinde iki sarnıç dışında başka bir yapı kalıntısı tespit edilememiştir. Kalenin kaba yonu taşlarla az miktarda harç kullanılarak örülen duvarları bölgedeki diğer Bizans yapılarıyla benzerdir. Kalenin 
bulunduğu tepenin eteklerinde üç kaya mezarı, iki işlik ve bir kule yapısı daha bulunmaktadır. Yazıtlar yardımıyla M.Ö. 4. yüzyılın ikinci yarısına tarihlenen kaya mezarlarından birinin kapı sövesinde ve işliklerden birinin üzerinde birer haç kazıması yer alır (İşler ve Tekoğlu, 2021, s. 4449). Haç kazımaları kaya mezarlarının ve işliğin Bizans döneminde ikinci kez kullanıldıklarını gösterir. Kalenin daha aşağı kesimlerinde birer kilisesi bulunan bazı küçük yerleşimler bulunur. Kalenin 1 km kadar kuzeybatısında ise 6. yüzyıla tarihlenen Alacahisar Manastırı yer almaktadır.

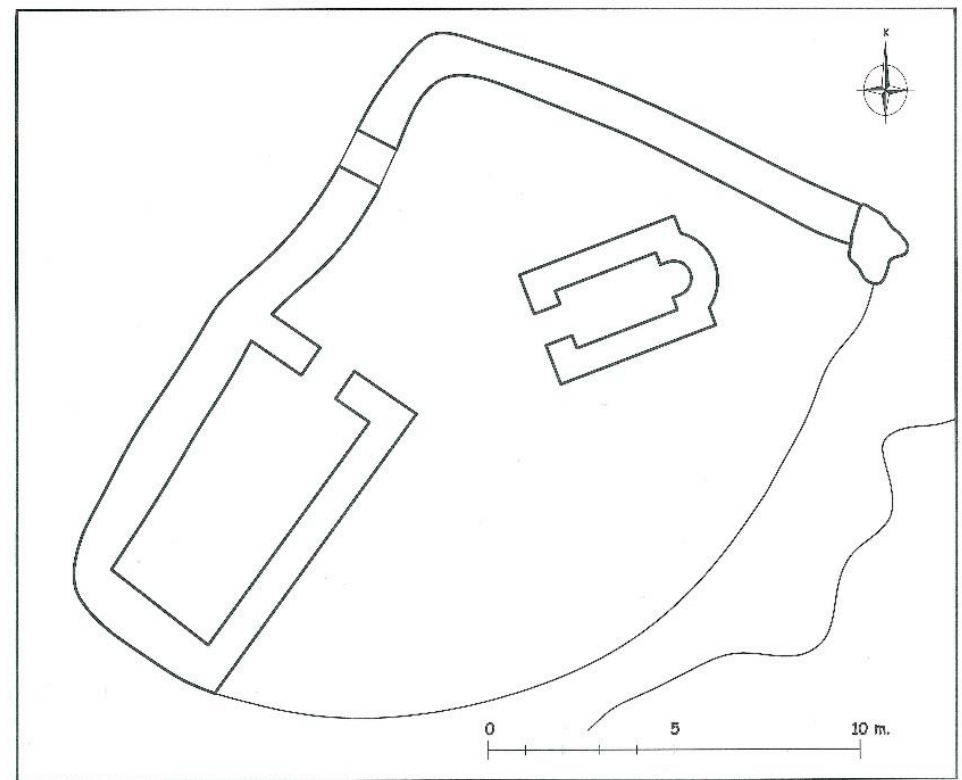

Resim 12: Göynük, Köte mevkiinde bulunan Bizans kalesinin planı (çizim: İşler 2018)

Göynük mahallesi Köte mevkiindeki Bizans kalesi Myros vadisini ve kıyıyı görebilen bir tepe üzerine konumlanmıştır. Kale, $1.4 \mathrm{~m}$ kalınlığındaki duvarlarıyla 18x13.70 m ölçülerinde güneybatı-kuzeydoğu yönünde yaklaşık dikdörtgen planlı olup toplam $255 \mathrm{~m}^{2}$ alanı kaplamaktadır (Resim 12). Kale oldukça zor ulaşılan sık çalılık bir alandadır. Duvarlarının büyük bölümü yıkık olmakla birlikte olasılıkla kuzeybatı duvarda bulunan bir kapı açıklığından yapıya girilir. Kalenin güney tarafı uçurum olmasından dolayı bu yöndeki duvarları günümüze ulaşmamıştır. Kalenin güneybatı köşesinde, kale duvarına bitişen tek odalı bir konut ile kalenin ortasında 3x1.65 m ölçülerinde bir şapel bulunmaktadır. Su kaynaklarına oldukça uzak olmasına karşın kale içinde sarnıç yapısı tespit edilememiştir. Kalenin 1600 m kadar kuzeydoğusunda kilise merkezli küçük bir yerleşim birimi yer alır.

Ayıveliler yerleşiminin $500 \mathrm{~m}$ kadar kuzeyinde, bir tepe üzerinde ikinci bir kale yapısı daha bulunmaktadır. Kalenin bulunduğu alandan tüm Kasaba ovası görülebilmektedir. $16 \times 34 \mathrm{~m}$ ölçülerinde kuzey-güney doğrultusunda dikdörtgen planlı olan kale oldukça düzgün bir plana sahiptir. Kalenin duvarları kaba yonu taşlarla az miktarda kireç harçı kullanılarak inşa edilmiştir. Kalenin duvarları büyük ölçüde yıkık, içi maki bitki örtüsüyle kaplıdır. Kalenin iç zemini kayalık olup, bir sarnıç dışında başka bir yapı kalıntısı tespit edilememiştir. Kalenin doğu duvarına bitişik haldeki sarnıç, dikdörtgen planlı, ana kayaya oyularak oluşturulmuştur. Sarnıcın örtüsü yıkıktır. Kaleye giriş batı duvarındaki $1.3 \mathrm{~m}$. genişliğindeki tek kapıdan sağlanmaktadır. İn situ olan kapı lentosunun dışa bakan yüzeyinde bir haç kabartması yer alır.

Yüzey araştırmalarımızda bulduğumuz altı kalenin ortak özelliği küçük boyutlu olmalarıdır. İçlerinde konut olabilecek yapı sayısı sınırlıdır ve çoğu sonraki bir evrede eklenmiştir. Asar Belen Tepe ve Yılanbaşı'ndaki dışında dört kalenin iç zemininin kayalık olması da ilginç bir özelliktir. Bu özelliklerinden dolayı küçük birer askeri birliğin konaklamasına uygun yapılardır. $\mathrm{Bu}$ 
yapılar olasılıkla sadece saldırılar sırasında geçici sığınak, erken uyarı ve gözetleme amaçlı kullanılmışlardır.

Araştırma alanımız dışında kalan Myra ve Dereağzı kaleleri diğer kalelere göre daha geniş bir alanı kaplamaktadır. Duvarları da daha yüksek olduğundan, her iki kalenin duvarları burçlarla desteklenmiştir. Ayrıca içlerinde bulunan kiliseler de kalabalık bir grubun kullanımına yöneliktir. Dolayısıyla Dereağzı ve Myra kalelerinin kalabalık askeri birlik/garnizon, diğer altı kalenin ise garnizona bağlı küçük askeri birlikler için olduğunu söylemek mümkündür.

Ayıveliler kalesi ve bölgedeki diğer kale yapılarıyla ilgili en büyük sorun tarihlendirmedir. Sadece Dereağzı kalesi, 1970'li yıllarda burada yüzey araştırmaları yürüten J. Morganstern tarafından 7. yüzyıl ortası ile 9. yüzyıl sonu arasındaki Arap saldırıları dönemine tarihlendirilmiştir (Morganstern 1980, s. 212) Kalelerin tarihlendirilmesinde arkeolojik buluntular oldukça yetersiz olmakla birlikte içlerinde bulunan şapel veya yakınındaki kilise ve konut yapıları ile haç bezemeli taş eserler, kalelerin Bizans döneminde inşa edildiklerini göstermektedir. Zira duvar yapım teknikleri de bölgedeki diğer Bizans yapılarıyla çok benzer özellikler göstermektedir. Kuşkusuz kalelerin inşa dönemlerinin tam olarak belirlenmesinde bölgenin tarihsel geçmişi yardımcı olabilir.

Myra antik kentinin bulunduğu Likya bölgesi, Avrupa ve Ege ile Doğu Akdeniz ve Misır arasında iletişimi sağlayan deniz yolu üzerinde konumlanmıştır. Likya limanları Batı'dan Mısır'a giden gemilerin açık deniz öncesi son uğrak noktasıydı. Likya'nın konumu Doğu ile Batı arasındaki ticaret ve haç yolculuklarından faydalanmasını sağlamıştır. Likya'nın iç kesiminde yetiştirilen tarım ürünlerinin kıyıdaki limanlar aracılığıyla Roma kentlerine ihraç edilmesiyle büyük bir ekonomik kazanç elde edilmekteydi. Likya'nın dağlı kesimi gemiler için gerekli olan reçine ve kereste bakımından da oldukça zengindi. Kıyının gerisinde, her açıdan korunaklı olan dağlık alanda, Geç Antik Çağ'dan başlayarak Bizans döneminde kısmen izole bir yaşam tarzı gelişti. İzole yaşam tarzı bölgede manastır yaşamının gelişmesine de yardımcı oldu. Dağlık alanda tarımdan elde edilen gelir sayesinde başkent İstanbul'daki imparatorluk yapılarıyla yarışabilecek özelliklere sahip manastır kompleksleri kuruldu. Özellikle Myra merkezdeki Aziz Nikolaos Kilisesi ve dağlık alandaki Sion Manastırı sahip olduğu tarım arazileri ve hacı ziyaretleri sayesinde büyük bir servete sahip olmuştu. Ancak bölgenin coğrafi konumu tarih boyunca bölgeyi korsanlar ve yabancı güçler için açık bir hedef haline getirmiştir. Tarih öncesi çağlardan başlayarak Türk dönemine kadar Likya bölgesine yönelik egemenlik isteklerinin ardı arkası kesilmemiştir. Çünkü Ege ve Akdeniz'e sahip olmanın yolu Likya limanlarından geçmektedir.

Likya bölgesinde yürütülmekte olan kazı çalışmaları, bölgenin orta Paleolitik dönemden başlayarak yerleşim gördüğünü göstermektedir (Çevik, 2015, s. 27). M.Ö. 15. yüzyıla ait Hitit ve Mısır kaynaklarında "Lukka" veya "Lukki" şeklinde adlandırılan bölgede, küçük topluluklar halinde Anadolu'nun yerli halkları yaşamaktadır. Lukka halkının denizcilikte oldukça başarılı olduğu Ege ve Akdeniz sahillerindeki kentlerle ticaret yaptıkları bilinmektedir. M.Ö. 6. yüzyıl ortalarından itibaren M.Ö. 360'a kadar, Lykia kentleri, Pers kralına vergi ödeyen yerel beyler (dynastlar) tarafından yönetilmiştir. M.Ö. 5. yüzyıl sonu ile M.Ö. 4. yüzyıl ilk yarısı Likya kent devletlerinin hem kendi aralarında hem de işgalci dış güçlerle mücadele ettikleri zorlu bir dönemdir (Çevik, 2015, s. 37).

İstila ve haydutluk/korsanlık faaliyetlerinden korunmak amaçlı olarak Klasik dönemin (M.Ö. 5.-4. yüzyıl başı) sonlarından başlayarak Helenistik dönemde (MÖ. 4.-1. yüzyıllar) Akdeniz sahili boyunca çok sayıda kule inşa edilmiştir ${ }^{2}$. Birkaç kattan oluşan kuleler, birbirlerini görecek biçimde kıyıya yakın tepelere ya da stratejik öneme sahip geçitlere konumlanmışlardı. Çoğunluğu tarım alanları yakınlarına konumlandığından bu yapılar "kule çiftlik evi" olarak da adlandırılmıştır (Kupke, 1992, s. 54 vd.; Alp, 1998, s. 27).

\footnotetext{
${ }^{2}$ Orta ve Doğu Likya' da bulunan Helenistik gözetleme kuleleri için bkz. Konecny, 1997.
} 
Kule çiftlik yapıları askeri olmaktan çok aslında insanların yaşamlarını sürdürdükleri konut alanıydı. Nitekim tüm kırsal dağlık alanda yaygın olarak inşa edilmişlerdir. Kule çiftlik yapılarının yakınında bulunan sarnıç, işlik ve mezarlar, insanların yakındaki tarım alanlarını ekip biçerek yaşamlarını sürdürdüklerini ve öldükten sonra evlerinin yakınındaki mezarlara gömüldüklerini göstermektedir. Kule çiftlik yapıları ortalama 7-9 m ölçülerinde kare planlı, çoğunluğu tek bir mekândan oluşmaktaydı. Duvarları düzgün kesilmiş kireçtaşından harç kullanılmadan inşa edilmiştir. Zeminden yükseltilmiş tek kapıdan ulaşılan bu yapılarda zemin kat depolama, üst katlar ise yaşam alanı olarak kullanılmaktaydı. Güvenlik için duvarlarında pencere açıklıklarına oldukça az yer verilmiş, varolanlar da dar ve mazgal biçiminde yapılmıştır. Bazılarının zemin katında ana kayaya oyularak oluşturulmuş sarnıçlar da bulunmaktadır. Nitekim bu yapılar bir saldırı durumunda bir ailenin güvenliğini ve ihtiyaçlarını bir süre karşılayabilecek düzeydeydi.

Kule çiftlik yapıları Bizans döneminde de kullanılmaya devam etmiştir. Birçoğu Bizans döneminde yeni kurulan yerleşimlerin çekirdeğini oluşturmuştur. Yılanbaşı ve Asar Belen Tepe'de bulunan Bizans kaleleri de bu kule yapılarının genişletilmesiyle inşa edilmiştir. Myros Vadisi'ni ve sahili gören onlarca kule çiftlik yapısı Bizans döneminde kırsal alanın güvenliği için gözetleme amaçlı olarak kullanılmış olmalıdır. Nitekim Bizans dönemi kaleleriyle kule çiftlik yapıları işlev olarak birbirlerini destekler şekilde konumlanmışlardır.

Anadolu'da Akdeniz bölgesi, istila ve korsanlık faaliyetlerinin en yoğun yaşandığı bölgelerin başında gelmektedir. Akdeniz bölgesinin en batısını oluşturan Likya bölgesi coğrafi yapısı korsanların barınması için oldukça elverişli imkânlar sunmaktaydı. Bölge sayısız koyun yanı sıra, korsan ve eşkıya gemilerinin saklanmasına imkân veren pek çok adacığı da barındırmaktaydı. Helenistik dönemde başta Olympos, Phaselis, Korykos olmak üzere birçok Lykia Birliği kentinde korsanların hakimiyeti görülmektedir. (Öztürk, 2012, s. 349). M.Ö. 67'de Akdeniz'de korsanlık ve haydutluk doruk noktasına ulaşmış; korsanlar neredeyse bütün Akdeniz'e hâkim olmuşlardı. (Öztürk, 2012, s. 352).

Likya bölgesinin M.S. 43 yılında İmparator Cladius'un emriyle Roma eyaleti haline gelmesinden sonra istila ve korsanlık faaliyetlerinin giderek azaldığı görülür (Öztürk, 2012, s. 352). 180 yılından sonra zaman zaman istila ve korsanlık faaliyetleri gözlense de genel olarak Likya halkı 7. yüzyıl başlarına kadar barış ve refah içinde yaşamıştır. Geç Antik Çağ olarak da adlandırılan bu dönemde meydana gelen depremler ve salgın hastalıklar Likya'nın kıyı kentlerindeki nüfusunun azalmasına neden olmuştur. Sadece 542 yılındaki veba salgını, kıyı kentlerinin nüfusunun yarıdan fazlasının ölümüyle sonuçlanmıştır. Üstelik kentlerde artan vergi yükü ve bazı şiddet olayları da halkın, özellikle sanatçıların/zanaatçıların kırsal alanlara yönelmesini hızlandırmıştır. Özetle Geç Antik Çağ' da kıyıdaki büyük kentlerin boşaldığı ve kırsal alanların önem kazandığg görülür. Bu dönemde kentlerdeki antik yapılar kullanım dışı kalmış, çoğu işlev değiştirmiş̧tir. Myra'nın liman yerleşimi Andriake'deki agora da mureks atölyesine dönüştürülmüştür (Aygün, 2017).

Geç Antik Çağ'ın sonunda 7. yüzyıl başlarında başta başkent İstanbul olmak üzere Anadolu'nun büyük bir kısmı Sasani saldırılarına ve istilasına uğramıştır. Arkeolojik bulgular Ksanthos, Limyra ve Likya'nın diğer kıyı kentlerinin Sasani saldırılarından etkilendiğini gösterir. Sasani saldırılarını Arap akınları izler. 655 yılında İmparator II. Konstans'ın komutasındaki Bizans donanmasının Likya kıyılarında meydana gelen savaşı kaybetmesi Akdeniz'in kontrolünün Araplara geçmesiyle sonuçlanır. Bu tarihten sonra yaklaşık 300 yıl boyunca Araplar Lykia ve Pamphylia kentlerine seferler düzenler. Arap akınları kalıcı olmaktan çok, kısa süreli ve kıyı kentlerinin zenginliklerini yağmalamaya yöneliktir (Hellenkemper 1993, s. 99-106).

673 ya da 674 yılında Araplar, Likya'ya yönelik yeni bir deniz seferine çıkmış, karada yapılan savaşta Arap ordusu yenilmiş, donanma ilk defa kullanılan "Rum Ateşi" ile yakılmıştır (Hellenkemper ve Hild, 2004, s. 117). 678 yılında yapılan İstanbul kuşatmasının da başarısızlıkla sonuçlanması ve dönüş yolunda firtınaya yakalanan donanmanın ağır kayıplar vermesi sonucunda 
Araplar ile Bizanslılar arasında barış antlaşması imzalanmıştır. Anlaşma ile Kıbrıs Adası ve gelirleri iki taraf arasında paylaşılmıştır. Anlaşma Bizans'ın bir süre rahatlamasını sağlamış, ancak Arapların Likya sahillerine yönelik seferleri devam etmiştir (Küçükaşçı, 2006, s. 379). Likya sahilleri ile Kıbrıs ve Rodos adaları hem Doğu Akdeniz ve Ege ticaretine hâkim olabilmek hem de fetihler için bir üs olarak kullanılıyordu. 716/7 yılında gerçekleştirilen İstanbul kuşatmasının ön hazırlıkları da burada yapılmıştır (Hellenkemper ve Hild, 2004, s. 117; Küçükaşçı, 2006, s. 378).

Abbasi donanması 790 yılında Kıbrıs ve Girit adalarına saldırır ve Antalya açıklarında karşılaşılan Bizans donanması mağlup edilerek kumandanı esir alınır. 802 Likya ve Karya Arapların kontrolü altına girer. I. Nikephoros döneminde (802-811) 807 yılında, Myra, Harun Reşid'in orduları tarafindan saldırıya uğrar (Hellenkemper, 1993, s. 103; Hellenkemper ve Hild, 2004, s. 121). Arapların, 860 yılında Antalya'ya, 904 yılında ise Likya'ya saldırmas1 Arap seferlerinin bu dönemde de devam ettiğini gösterir (Küçükaşçı, 2006, s. 380). Nitekim kıyının gerisinde dağlık alanda yaşayan halk 9. yüzyıla kadar süren Arap akınlarından daha az etkilenmiş olmalıdır. Zor ulaşılan dağlık alanda inşa ettikleri savunma yapıları sayesinde güvenli yaşamlarını sürdürebilmişlerdir.

Makedon Hanedanlığ zamanında (867-1056) donanma gücünü arttırmak gibi Arap saldıılarına karşı yeni önlemler alınır. Bizanslıların Doğu Akdeniz ve Ege'de kazandıkları başarılar ve 964 yılında Kıbrıs Adası'nın ele geçirilmesi, denizlerin kontrolünün yeniden Bizanslıların eline geçmesini sağlar. 10. yüzyıldan 11. yüzyıl ortalarına kadar sürecek olan güven ve huzur ortamında ekonomik hayat yeniden canlanır (Foss, 1996, II, s. 5, 34).

1034 y1lında Kuzey Afrikalı Zirid'lerin Myra'ya saldırmasının ardından 1035 yılında Myra kalesi güçlendirilir. Ayrıca 1042/43 yılında Aziz Nikolaos kilisesi yenilenir (Doğan, 2018, s. 41). Ancak 1087 yılında bir grup Barili tüccar/korsan Myra'daki Aziz Nikolaos kilisesini yağmalayarak Aziz Nikolaos'un röliklerini Bari'ye kaçırır (Doğan, 2018, s. 44).

Bizans İmparatoru I. Manuel Komnenos döneminde (1143-1180) İtalyan denizci şehir cumhuriyetleriyle bağlantıları kuvvetlendirmek ve destek bulmak amacıyla 1169'da Cenova, 1170 'de Pisa ile anlaşmalar yapılır. Anlaşmalar gereğince Likya kıyıları İtalyan şehir cumhuriyetlerine kullanım imtiyazı ile açılmıştır. Ancak I. Andronikos (1183-1185) döneminde ilişkilerin bozulması sonucu, Finike'yi üs olarak kullanan Pisalıların bölgede korsanlığa başladığı sahil yerleşimlerini yağmaladıkları görülür. 12. yüzyılda Türklerin bölgeye yerleşmesiyle bölgedeki Bizans egemenliği de son bulur (Foss, 1996, II, s. 41; Erdem, 2006, s. 245-246).

\section{Sonuç}

Sonuç olarak yüzey araştırmalarımızda keşfettiğimiz kaleler, Myra antik kentinin kırsal yerleşimleri için hayati öneme sahipti. Tamamı kıyıdan gelebilecek saldırılar için birbirleriyle bağlantı olarak inşa edilmişlerdir. Özellikle tarihsel veriler ve yakındaki dini yapıların bezemeleri bu kalelerin 7. ve 9. yüzyıllar arasında, Arap akınlarından korunmak amaçlı inşa edildiklerini göstermektedir. Söz konusu kaleler 11.-12. yüzyıllardaki korsanlık faaliyetlerinden korunmak için de kullanılmış olmalıdır. Kalelerin birçoğu denizden gelebilecek tehlikelere göre konumlandığından, olasılıkla 12. yüzyılda kuzeyden bölgeye gelen Türk yerleşimcilere karşı etkisiz kalmıştır. Nitekim Türklerin 12. yüzyılda bölgeye yerleşmesiyle kaleler işlevsiz kalmış ve zamanla terk edilmiştir. 


\section{Kaynakça}

Alp, O. (1998). Şehircilik Açısından Romanizasyon Sürecinde Likya Kentleri. [yüksek lisans tezi], Ankara Üniversitesi, Arkeoloji ve Sanat Tarihi Bölümü.

Aygün, Ç. A. (2017). Andriake mureks boya endüstrisi/Andriake murex dye industry, Adalya Suppl. 14, Koç Üniversitesi Suna\&İnan Kıraç Akdeniz Medeniyetleri Araştırma Merkezi.

Borchhardt, J. (1975). Die akropolis von Myra. Myra eine Lykische metropole in antiker und byzantinischer zeit, Ed. J. Borchhardt, Gebr. Mann Verlag, 45-47.

Çevik, N. (2015). Likya kitabı, Suna\&İnan Kıraç Akdeniz Medeniyetlerini Araştırma Enstitüsü.

Doğan, S. (2018). Kaynaklar eşliğinde Aziz Nikolaos Kilisesi'nin tarihi. Aziz Nikolaos Kilisesi kazıları 1989-2009, Homer Kitabevi, 33-62.

Erdem, İ. (2006). Ortaçağ sonlarında Likya Levant ticareti ve Türkmenler (12.-15. yy.). III. Uluslararası Likya sempozyumu, sempozyum bildirileri, (07-10 Kasım 2005), cilt I, (ed. K. Dörtlük vd.), Akmed Yayınları, 243-251.

Foss, C. (1994). The Lycian Coast in the Byzantine age. Dumbarton Oaks Papers, (48), 1-52.

Foss, C. (1996). Cities, fortresses and villages of Byzantine Asia Minor.

Foss, C. \& Winfield, D. (1986). Byzantine fortifications: An introduction, University of South Africa.

Hellenkemper, H. (1993). Lykien und die Araber, Akten Des II. internationalen Lykien-symposions, Ed. J. Borchhardt, G. Dobesch, Wien: Österreichische Akademie der Wissenschaften, 99106.

Hellenkemper, H. G. \& Hild, F. (2004). Lykien und Pamphylien, tabula imperii Byzantini 8, 3 cilt.

İşler, B. \& Tekoğlu, Ş. R. (2021). Rock-cut tombs and two Lycian inscriptions from KarabelÇamdağ 1 . ADALYA (24), 43-59.

Konecny, A. (1997). Turmgehöfte in zentral und ostlykien.

Kupke, B. (1993). Arbeiten im stadtgebiet von Kyaneai Lykische studien I. Die Siedlungkammer von Kyaneai, 9-24.

Küçükaşçı, M. S. (2006). VII.-XII. yüzyıllarda Likya'ya Arap ilgisi. III. Uluslararası Likya sempozyumu, sempozyum bildirileri, (07-10 Kasım 2005), cilt 1, (ed. K. Dörtlük vd.), Akmed Yayınları, 375-383.

Morganstern, J. (1980). The Settlement at Dereağzı: A preliminary report on the 1974 and 1975 seasons. Türk Arkeoloji Dergisi 25 (1), 201-220.

Morganstern, J. (1993). The fort at Dereağzl: and other material remains in its vicinity: from Antiquity to the Middle Ages, Ernst Wasmuth.

Öztürk, H. S. (2012). İ.Ö. II.-İ.S. IV. yüzyıllarda Lykia'nın kırsal güvenlik problemleri. Uluslararası genç bilimciler buluşması I. Anadolu Akdenizi sempozyumu 04-07 Kasım 2009/ International young scholars conference I: mediterranean Anatolia 04-07 November 2009, 347-360.

Wurster, W. W. (1993). The fort. The fort at Dereağzl: and other material remains in its vicinity: from Antiquity to the Middle Ages, ed. J. Morganstern, Ernst Wasmuth, 27-63. 